\title{
17. CALCAREOUS NANNOPLANKTON AND SILICOFLAGELLATE BIOSTRATIGRAPHY AT REYKJANES RIDGE, NORTHEASTERN NORTH ATLANTIC (DSDP LEG 49, SITES 407 AND 409)
}

\author{
Erlend Martini, Geologisch-Paläontologisches Institut der Universität. Frankfurt am Main, Germany
}

\section{INTRODUCTION}

During Leg 49 three sites were drilled on the west flank of the Reykjanes Ridge south of. Iceland (Figure 1): Site 409 , near the Reykjanes Ridge axis; Site 408, on anomaly 6 (about $20 \mathrm{~m} . \mathrm{y}$.); and Site 407, on anomaly 13 (about 38 m.y.). Eighty-five samples from Hole 407 and 9 samples from Hole 409 were selected for a shore-lab study on calcareous nannofossils and silicoflagellates. All samples were investigated by light microscope techniques. In addition, 17 samples from Hole 407 and 4 samples from Hole 409 were also studied for calcareous nannofossils with a scanning electron microscope; these samples are indicated by asterisks in Tables 1 and 2 .

\section{ZONATION OF CALCAREOUS NANNOFOSSILS AND SILICOFLAGELLATES}

In the Reykjanes Ridge area the standard calcareous nannofossil zonation (Martini, 1971) was used, although certain intervals had to be combined because of the high latitudinal position of the sites. The middle Oligocene to lower Miocene standard nannofossil zones were identified by their index species or substitute species already used in the North European area (Müller, 1976). Also, Zones NN 10 (Discoaster calcaris Zone) and NN 11 (Discoaster quinqueramus Zone) could be identified on the basis of the index species, but difficulties arose in the upper Miocene and Pliocene interval, because species commonly used for subdivision - like discoasters or ceratoliths - are too rare or absent in this area. Similar to the usage in the Norwegian-Greenland Sea (Leg 38: Müller, 1976; Martini and Müller, 1976), only two intervals could be

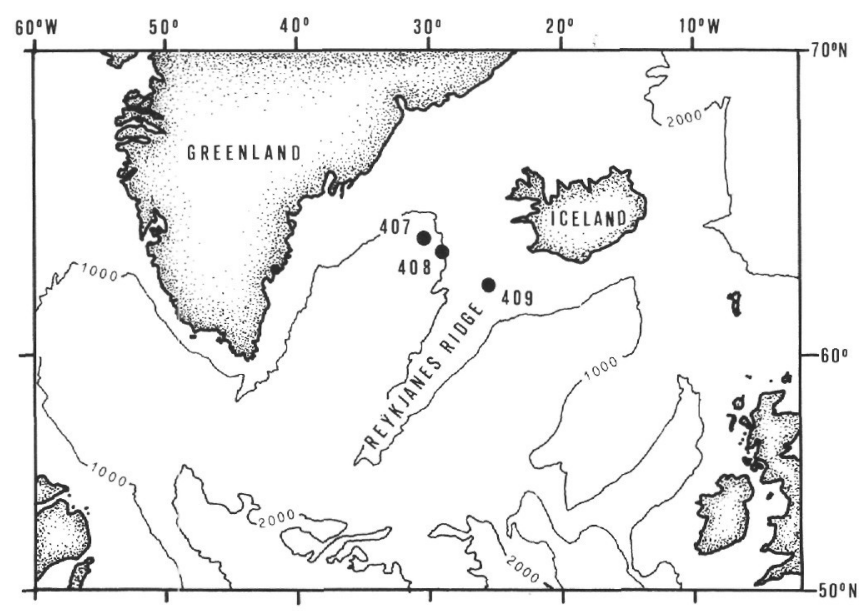

Figure 1. Location of sites drilled in the Reykjanes Ridge area during Leg 49. differentiated. The interval with Reticulofenestra pseudoumbilica is equivalent in this case to standard nannofossil Zones NN 12 to NN 15, since Zone NN 11 could be identified by the presence of Discoaster quinqueramus and the top of Zone NN 15 is defined by the last occurrence of Reticulofenestra pseudoumbilica. Above the last occurrence of Reticulofenestra pseudoumbilica the assemblages in most of the "glacial part" are characterized by the presence of Pseudoemiliania lacunosa. This assemblage is equivalent to standard nannofossil Zones NN 16 to NN 19, since the last occurrence of Pseudoemiliania lacunosa defines the top of Zone NN 19. Standard nannofossil Zone NN 20 (Gephyrocapsa oceanica Zone) and Zone NN 21 (Emiliania huxleyi Zone) were identified as originally defined.

Because the onset of glacial conditions in the area investigated occurred much earlier than in low and middle latitudes, the Pliocene/Pleistocene boundary, as defined in the open oceans, is difficult to identify. The discoasters commonly used for identification of this boundary have their last rare occurrences within the range of Reticulofenestra pseudoumbilica in Hole 407, and have not been found in any sample above the last occurrence of Reticulofenestra pseudoumbilica. The proposition of Hoffman (1976) to replace the zonal index numbers NN 19 to NN 21 by NQ 1 to NQ 3, indicating the Quaternary position of these zones, is not followed here, because of the different onset-times of glaciation in low and high latitudes and difficulties in identifying the base of the Quaternary on the basis of calcareous nannofossils in high latitudes; he is correct, however, in pointing out that the symbol NN for Quaternary nannofossil zones is somewhat misleading.

The silicoflagellate zonation used in this report for the Neogene and the glacial part is virtually the same as used for Leg 38 (Martini and Müller, 1976), but since some intervals in Hole 407 are barren of silicoflagellates and a hiatus is present between the lower and upper Miocene, not all zones in the Miocene/lower Pliocene have been identified. Also, the top of the Distephanus speculum Zone may not be properly defined in this area or in the Norwegian-Greenland Sea by the first occurrence of Distephanus octangulatus. In the highest Hole 407 sample containing silicoflagellates $(1-1,50-51 \mathrm{~cm})$, which belongs to the Emiliania huxleyi Zone (NN 21), Distephanus octonarius is the only species present, whereas Distephanus speculum and Distephanus octangulatus, which are present in fair numbers in the equivalent interval in the North Pacific (according to Ling, 1973), are obviously missing.

Correlations between both zonations in high latitudes were outlined in Martini and Müller (1976, Figure 3). Some minor differences are discussed below. 
TABLE 1

Distribution of Calcareous Nannofossil in Selected Samples From Site 407 and Indication of Nannofossil Zones

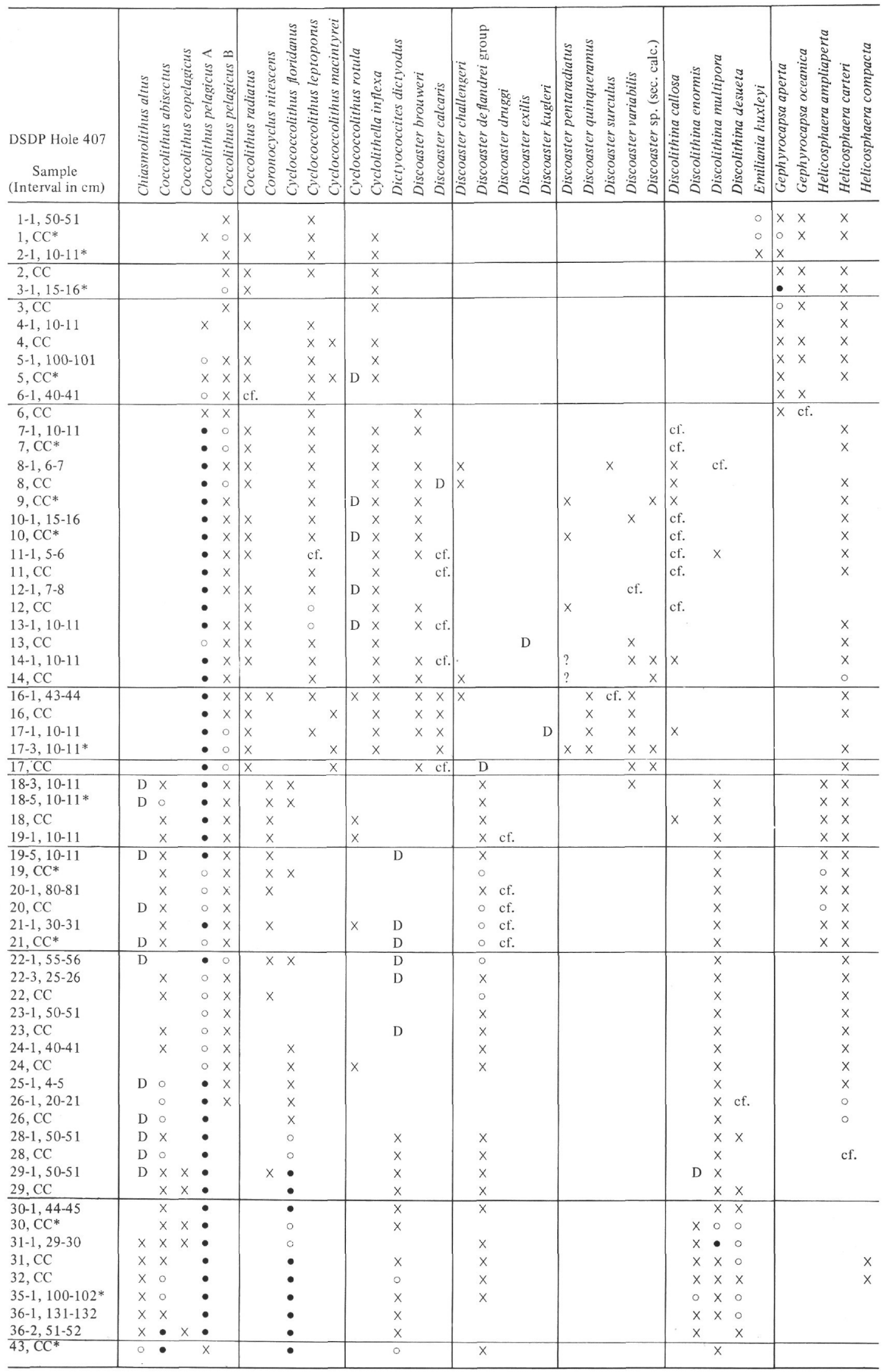

Note: $X=$ rare to few,$O=$ common, $\bullet=$ abundant,$D=$ displaced from older strata,$C=$ Cretaceous nannofossils. Preservation: $\mathrm{P}=$ poor, $\mathrm{M}=$ moderate, $\mathrm{G}$ = good. 
NANNOPLANKTON AND SILICOFLAGELLATE BIOSTRATIGRAPHY

TABLE 1 - Continued

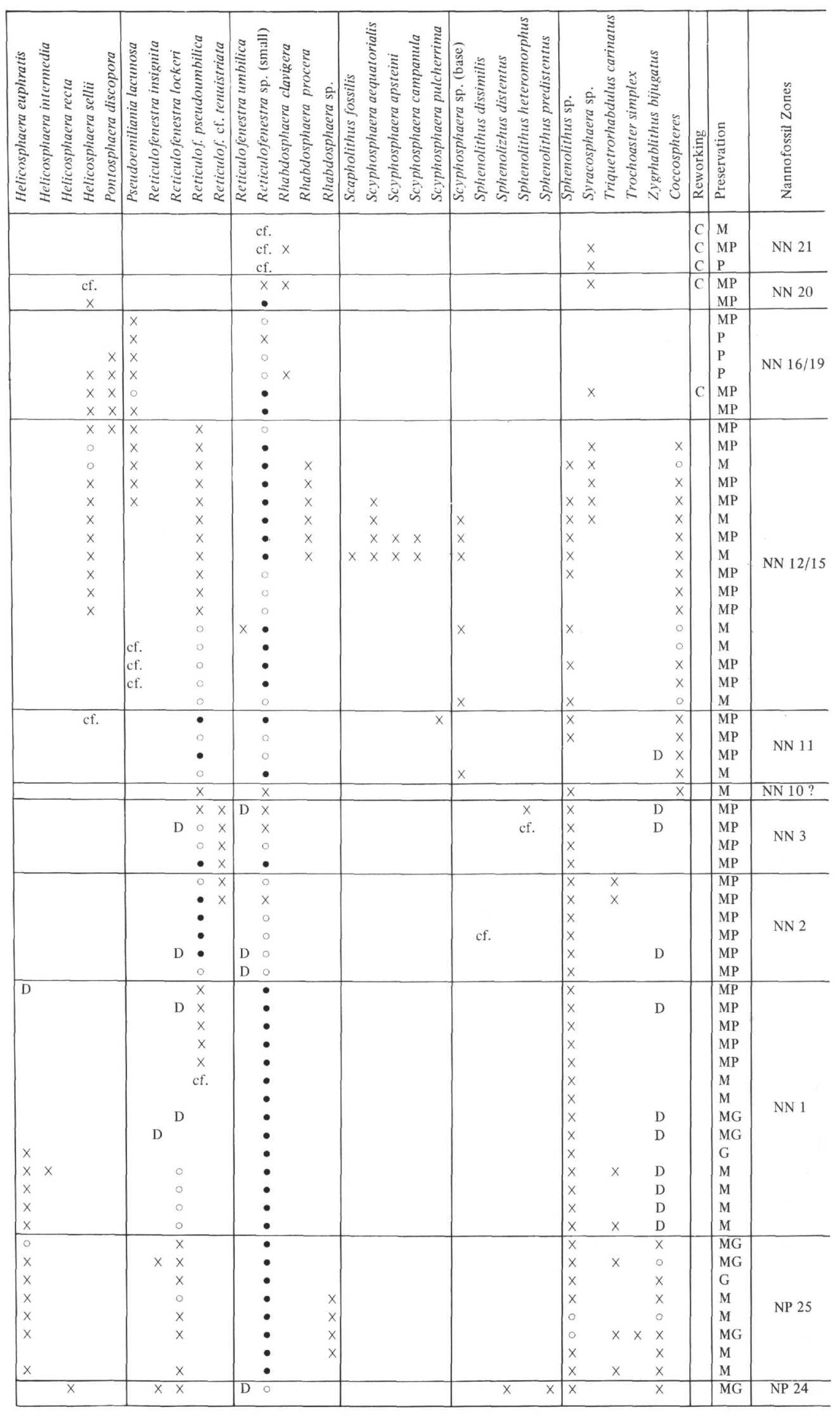

535 
TABLE 2

Distribution of Calcareous Nannofossil in Selected Samples From Site 409 and Indication of Nannofossil Zones

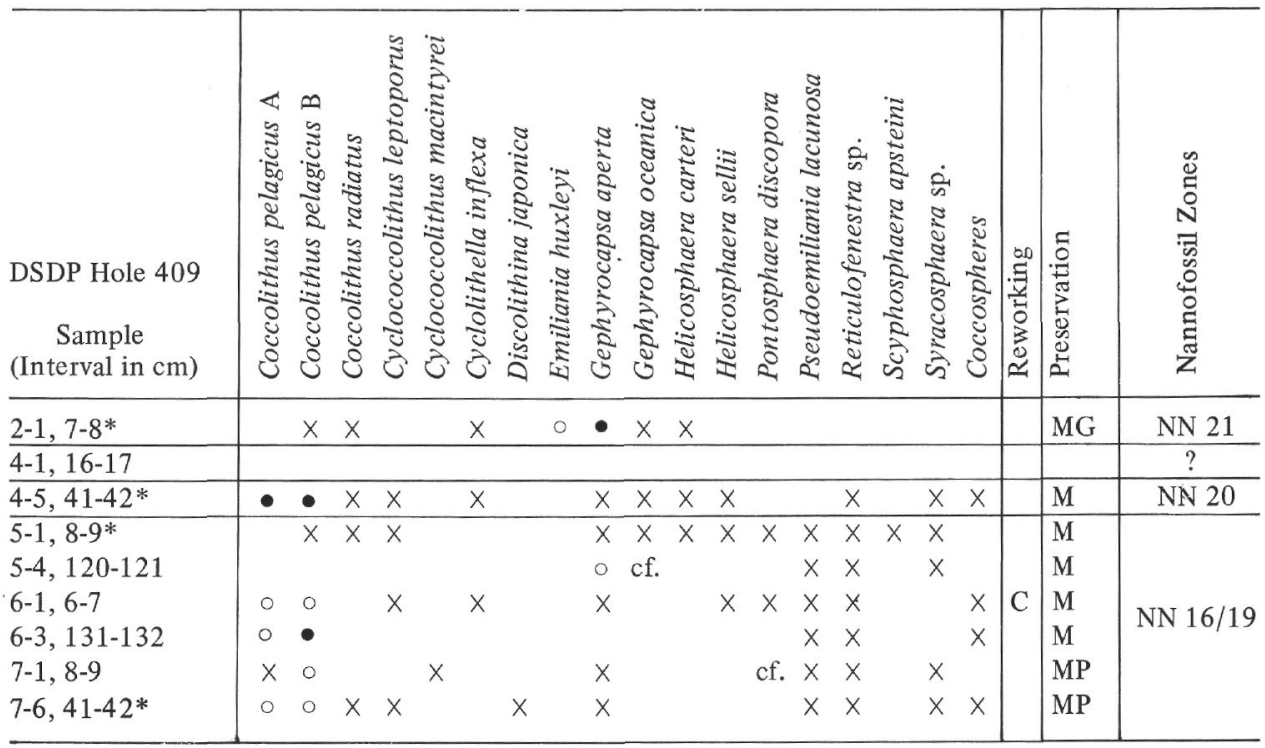

Note: $X=$ rare to few $O=$ common, $\bullet=$ abundant, $\mathrm{C}=$ Cretaceous nannofossils. Preservation: $\mathrm{P}=$ poor, $\mathrm{M}=$ moderate, $\mathrm{G}=$ good.

\section{SITE 407}

At Site $407\left(63^{\circ} 56.32^{\prime} \mathrm{N}, 30^{\circ} 34.56^{\prime} \mathrm{W}\right.$, water depth 2472 $\mathrm{m}), 48$ cores were recovered during continuous coring. The first basalt flow occurs at 300.5 meters. Three intercalated sediment bodies are present within the basalt sequence. The hole was terminated in basalt, at $\mathbf{4 5 8 . 5}$ meters sub-bottom. The shipboard party differentiated four lithologic units within the continuous sediment column (Figure 2).

The first unit ( 0 to $46.3 \mathrm{~m}$ ) is described as calcareous mud with an intermediate zone $(15.5$ to $25.0 \mathrm{~m})$ of marly calcareous ooze and a thin ash layer near the base. It corresponds to the glacial part of the column. Rare silicoflagellates, identified as Distephanus octonarius, occur in Cores 1 to 3 and in Section 6-1. Samples between Section 4-1 and Sample 5,CC are barren of silicoflagellates. This interval is placed in the Distephanus speculum Zone. Calcareous nannofossils in this unit belong to standard nannoplankton Zones NN 16/19, NN 20, and NN 21. The assemblages have rather low diversity and are dominated by Gephyrocapsa aperta and Emiliania huxleyi from Core 1 to Section 2-1, and below, down to Core 6, by small specimens of Reticulofenestra species. Helicosphaera carteri and large specimens of Coccolithus pelagicus are also present in almost all samples. The last occurrence of Pseudoemiliania lacunosa is in Sample 3,CC; this species is present in Hole 407 from Sample 8,CC up to Sample 3,CC. Other species and their distribution are listed in Table 1.

Within this first unit, reworked Cretaceous calcareous nannofossils occur in varying amounts in several samples, and include Arkhangelskiella cymbiformis, Eiffellithus turriseiffeli, Micula staurophora, Nephrolithus frequens, Prediscosphaera cretacea, and Watznaueria barnesae, which is in perfect conformity with the glacial part in holes of Leg 38 in the Norwegian-Greenland Sea (Müller, 1976).
Zonal boundaries occur between Section 2-1 and Sample 2,CC (NN 20 - NN 21), between Section 3-1 and Sample 3,CC (NN 19 - NN 20), and between Section 6-1 and Sample 6,CC (NN 12/15 - NN 16/19). The rather abrupt last occurrences of Discoaster brouweri, Reticulofenestra pseudoumbilica, and Distephanus boliviensis (species which otherwise do not have their last occurrences in common), between Samples 6,CC and 6-1, 40-41 cm, at the level of a lithologic change, leads to the suspicion that a hiatus may be present. The missing interval is difficult to calculate on the basis of the meager calcareous nannofossil and silicoflagellate assemblages, but may include part of the upper Pliocene.

Lithologic Unit 2, between 46.3 and 160.7 meters (Cores 6 to 18), is very uniform, and consists of soft nannofossil ooze which changes to chalk in Core $13(115 \mathrm{~m}$ sub-bottom). The upper part of this unit, between Samples $6, \mathrm{CC}$ and $14, \mathrm{CC}$, is placed in combined Zones NN 12/15, on the basis of the calcareous nannofossil assemblage, but it is open to discussion whether or not part of Zone NN 15 is missing as a result of a possible hiatus within Core 6 . The last occurrences of sphenoliths, however, are in Sample $7, \mathrm{CC}$. The calcareous nannofossil assemblage is strongly dominated by abundant Coccolithus pelagicus, (type A without and type B with central cross; See tables 1 and 2 ), whole coccospheres of which are frequent in all samples investigated, and by small specimens of one or more Reticulofenestra species. Discoasters are rare and in many cases difficult to identify, as indicated by "cf." identifications, but show similarities to the Rockall Bank assemblages (Leg 12, Perch-Nielsen, 1972), whereas they are totally missing in the Norwegian-Greenland Sea (Müller, 1976). In Samples 8,CC to 10,CC, Scyphosphaera species occur rather frequently; they are otherwise extremely rare or missing. At about the same level, some 


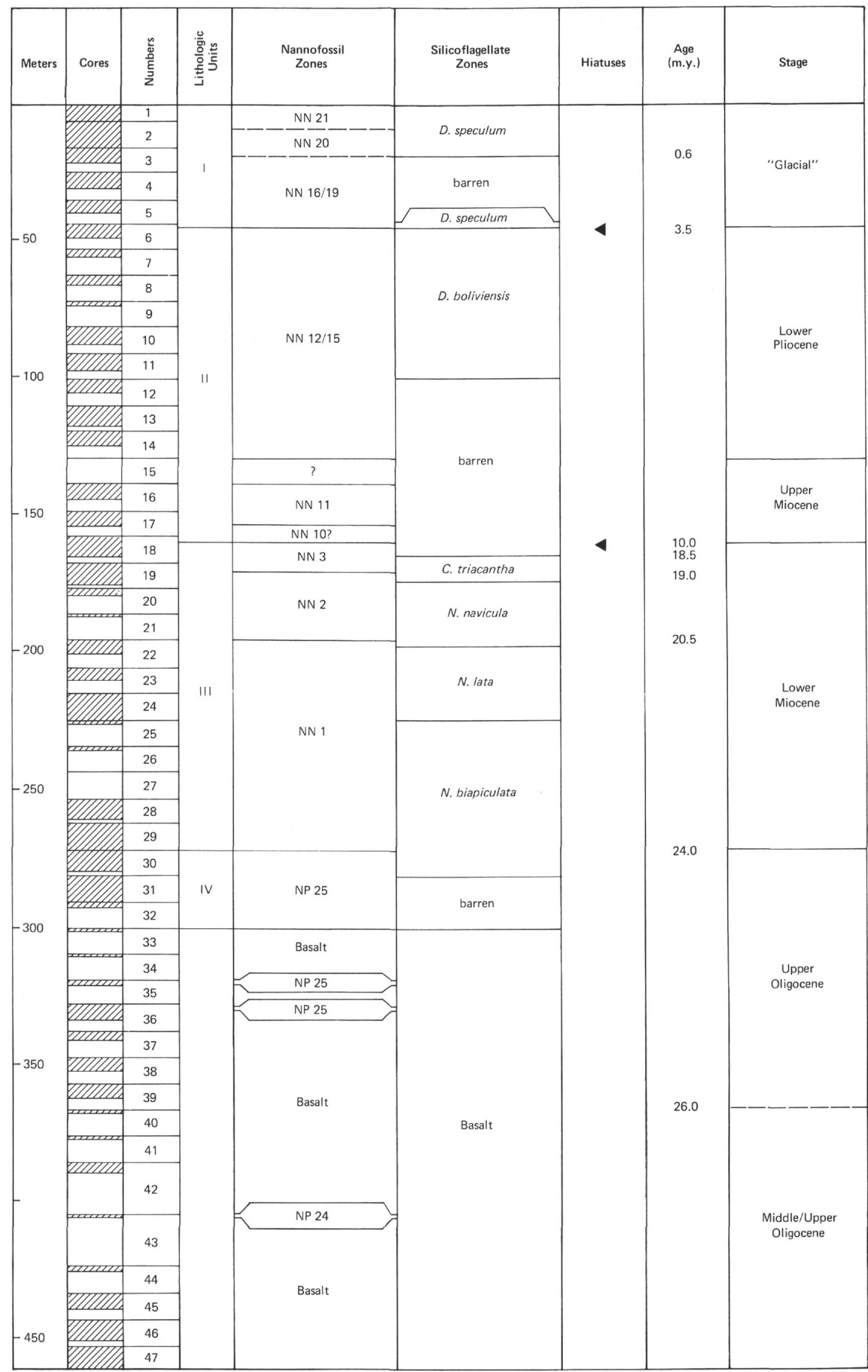

Figure 2. Site 407 summary figure with cored and recovered intervals, lithologic units, nannofossil zones, silicoflagellate zones, occurrences of hiatuses, and indication of ages. 
other delicate species like Syracosphaera sp., Scapholithus fossilis, and Rhabdosphaera procera occur; this indicates not only better preservation but also influx of slightly warmer water. Between Samples 16-1, 43-44 cm and $17, \mathrm{CC}$, the upper Miocene can be identified on the basis of rare Discoaster quinqueramus, which does not, however, occur in Sample 17,CC. Consequently, Sample 17,CC is tentatively placed in Zone NN 10 (Discoaster calcaris Zone), and the other samples in Zone NN 11 (Discoaster quinqueramus Zone). For distribution of other species, see Table 1. A few displaced specimens (e.g., Coccolithus abisectus, Discoaster kugleri, Discoaster deflandrei, Discoaster exilis, and Zygrhablithus bijugatus) occur in this unit and are listed with the letter " $D$ "' (displaced) in Table 1. Silicoflagellates are present only in the interval from Sample 6,CC to Sample 11,CC, and can be placed in the Distephanus boliviensis Zone. Distephanus boliviensis and Distephanus speculum are present in all samples. The last occurrence of Mesocena diodon is in Sample 9,CC, which is in accordance with the distribution of this species in the Norwegian-Greenland Sea. Noteworthy also is the rare occurrence of Distephanus polyactis in the lower part of Core 11. Samples $12-1,7-8 \mathrm{~cm}$ to $18-5,10-11 \mathrm{~cm}$ are barren of silicoflagellates.

At 160.7 meters (Section 18-2), the nannofossil chalk abruptly changes to siliceous nannofossil chalk (lithologic Unit 3) with a slight increased ash content and some real ash layers in Core 24. This unit extends down to 272.0 meters (Core 29). Between Samples 17,CC and 18-3, 10-11 cm, a hiatus, which probably coincides with the lithologic change, can be noted on the basis of the calcareous nannofossil assemblages. Standard nannofossil Zones NN 4 to part of NN 10 are missing — that is, the entire middle Miocene and part of the upper Miocene. Within lithologic Unit 3, calcareous nannofossil Zones NN 1 (Triquetrorhabdulus carinatus Zone) to NN 3 (Sphenolithus belemnos Zone) can be identified, although index species are rare or even missing. The base of Zone NN 1 is placed at the last frequent occurrences of Zygrhablithus bijugatus and Discolithina enormis; that is, between Samples 29,CC and $30-1,44-45 \mathrm{~cm}$. The base of Zone NN 2 (Discoaster druggi Zone) is indicated by first specimens of Discoaster cf. druggi in Sample 21,CC, and the top of the same zone can be identified by the last occurrence of Triquetrorhabdulus carinatus in Sample 19-5, 10-11 cm. Also helpful for the evaluation of these boundaries are first or last occurrences of other species such as Dictyococcites dictyodus, Helicosphaera carteri, Helicosphaera ampliaperta, and Sphenolithus heteromorphus. Sphenolithus heteromorphus, present in typical specimens in Sample 18-3, 10-11 cm and with ancestral forms in Sample 18-5, 10-11 cm, has its first occurrence just below the extinction of Sphenolithus belemnos elsewhere, and it seems realistic to include these samples in our Zone NN 3, although Sphenolithus belemnos was not found in the present material. Sphenolithus delphix, originally described by Bukry (1973) from eastern equatorial Pacific specimens from uppermost Oligocene (NP 25) to lowermost Miocene (NN 1, lower part), occurs in typical specimens in Samples $20-1,80-81 \mathrm{~cm}$ (NN 2) and $18-5,10-11 \mathrm{~cm}$ (NN 3), but otherwise were not noted in the Reykjanes Ridge area in the interval from which they were originally described. Helicosphaera ampliaperta, present in Samples $21, \mathrm{CC}$ to $18-3,10-11 \mathrm{~cm}$, is especially common in Samples 20,CC and 19,CC. Displaced nannofossils from the Oligocene, like Chiasmolithus altus, Dictyococcites dictyodus, Reticulofenestra lockeri, Reticulofenestra umbilica, and Zygrhablithus bijugatus, are present in quite a few samples of this unit, and indicate a more or less continuous supply of reworked material.

Silicoflagellates in samples from lithologic Unit 3 can be placed in the Naviculopsis biapiculata Zone, Naviculopsis lata Zone, and tentatively in the Corbisema triacantha Zone (Table 3). Assemblages found are similar to those of the Norwegian-Greenland Sea, but species are not as common and some seem to have had a slightly different distribution in time; this may be a consequence of the scarcity of these species in the present material. Among species of the genus Naviculopsis, $N$. iberica overlaps $N$. lata only in Sample $22-3,25-26 \mathrm{~cm}$, whereas in the Norwegian-Greenland Sea at Site 338 it has a much greater overlap with $N$. lata (Martini and Müller, 1976). Also, N. quadratum (Figure 3) is extremely rare and was only found, together with Cannopilus hemisphaericus (Figure 4), in Sample 21-1, $30-31 \mathrm{~cm}$, about the middle of the range of $N$. navicula; in areas elsewhere it has a slightly longer range than $N$. navicula (Martini and Müller, 1976; Steininger et al., 1976). Corbisema triacantha, fairly common in the Naviculopsis lata Zone in the present material, is missing in the Naviculopsis navicula Zone and the Corbisema triacantha Zone, in contrast to its occurrence in the Norwegian-Greenland Sea. For the distribution of other species, consult Table 3. Correlations between silicoflagellate zones and the calcareous nannofossil zones in the upper part of this unit are similar to those indicated by Martini (1972) for the Mediterranean, and show only slight differences, probably owing to the somewhat peculiar distribution of Naviculopsis species in this area, as discussed above.

Lithologic Unit 4 begins with a marked decrease in sponge spicules and ash content in the nannofossil chalk in Core 30 at 272.0 meters. From the base of Core 30 downward, volcanic particles are frequent, and the sediment is classified as nannofossil chalk-basalt pebble gravel. Below Core 32 and below 300.5 meters, massive basalts were encountered. Calcareous nannofossils within this interval are characterized by the abundant occurrence of Coccolithus pelagicus, Cyclococcolithus floridanus, and Reticulofenestra sp., together with fairly common Coccolithus abisectus, several Discolithina species (including Discolithina enormis), Zygrhablithus bijugatus, and in the lower part, Chiasmolithus altus. Triquetrorhabdulus carinatus, as in the intercalated sediment of Cores 35 and 36, is present only sporadically. Because Helicosphaera recta is missing in this area in the upper Oligocene, Discolithina enormis, together with Zygrhablithus bijugatus, is taken as a substitute species to define the top of Zone NP 25 (Sphenolithus ciperoensis Zone), in accordance with common usage in the North Sea basin and in the Norwegian-Greenland Sea (Martini and Müller, 1975; Müller, 1976). The top of Zone NP 25 was taken as top of the Oligocene, and the Oligocene/Miocene boundary is placed between Samples 29,CC and 30-1, 
TABLE 3

Distribution of Silicoflagellates in Selected Samples From Site 407 and Indication of Silicoflagellate Zones

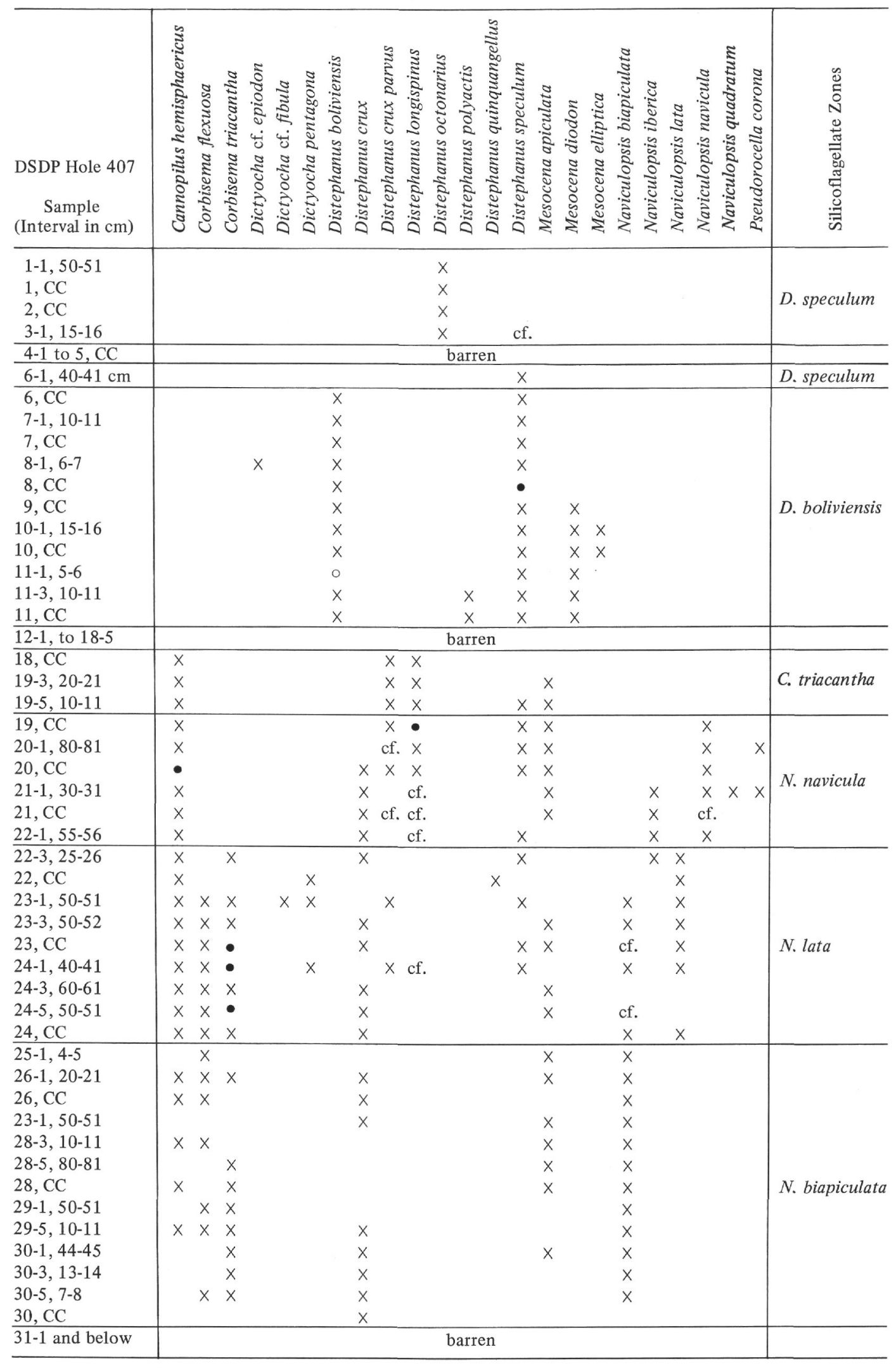

Note: $\mathrm{X}=$ rare to few $\bullet=$ common or abundant. 


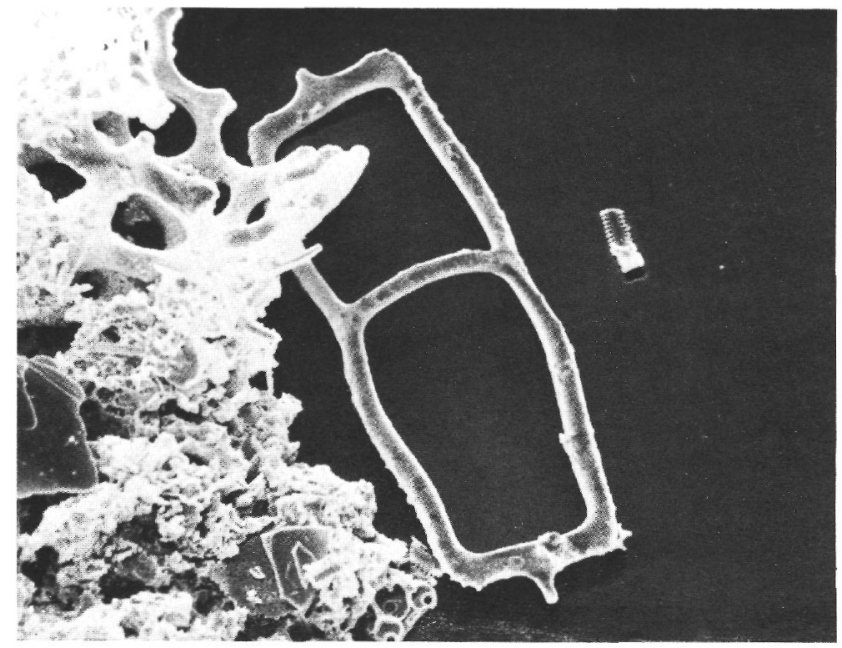

Figure 3. Naviculopsis quadratum (Ehrenberg). Distal side, SEM 1000 X; Sample 407-21-1, 30-31 cm. Naviculopsis navicula Zone.

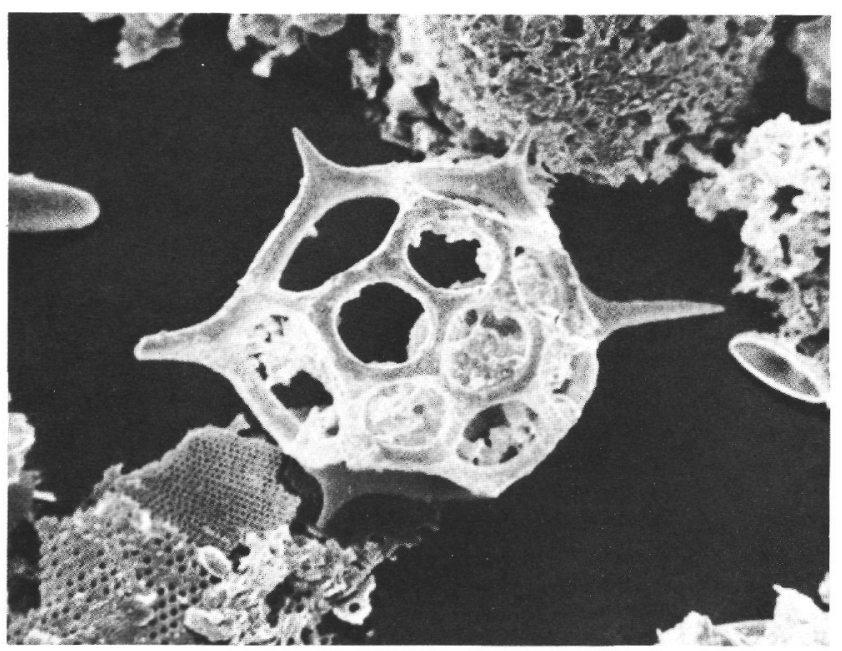

Figure 4. Cannopilus hemisphaericus (Ehrenberg). Distal side, SEM 1000 X; Sample 407-21-1, 30-31 cm. Naviculopsis navicula Zone.

$44-45 \mathrm{~cm}$, which also coincides in the present material with the sedimentary change.

Silicoflagellates occur only in samples of Core 30, and are totally missing below. The assemblage, rather meager, consists of Corbisema triacantha, Distephanus crux, and Naviculopsis biapiculata in most samples, and is placed in the Naviculopsis biapiculata Zone. Regarding the upper limit of the Naviculopsis biapiculata Zone, some explanations seem necessary, since in the Norwegian-Greenland Sea this boundary could not be properly correlated with the nannofossil zonation, owing to an unfavorable sedimentary section. The first occurrence of Naviculopsis lata in Hole 338 is at 19-2, 10-11 cm, just on top of an interval containing a meager calcareous nannofossil assemblage which indicates the middle to upper Oligocene - probably nannofossil Zone NP 24, since Discolithina enormis is not present (Martini and Müller, 1976; Müller, 1976). In the Paratethys, the Naviculopsis lata Zone was reported from the Egerian, which is approximately equivalent to nannofossil Zones NP 24 (upper part) to NN 1 (Steininger et al., 1976); but since all samples containing Naviculopsis lata are from isolated localities with no continuous siliceous section available, the lower boundary of this particular zone may be somewhere in the upper part of the Oligocene, although Bachmann (1970) speculated that the first occurrence of $N$. lata may be in the middle Oligocene. Investigations in the Mediterranean (Ling, 1972; Martini, 1972; Sanfilippo et al., 1973) as well as in the Antarctic Ocean (Leg 28: Ciesielski, 1975) could not solve the problem because no continuous sampling was possible or the base was missing or not siliceous. There is agreement, however, that at least most of Zone NN 1 is represented by the Naviculopsis lata Zone in siliceous sequences.

Below 300.5 meters, thin beds of intercalated sediments occur within the basalts in Cores 35 ( 320.3 to $321.3 \mathrm{~m}$ ), 36 ( 329.4 to $331.2 \mathrm{~m}$ ), and 43 (405.0 to $405.4 \mathrm{~m})$. Samples from Cores 35 and 36, listed in Table 1, contain the same nannofossil assemblage as those from lithologic Unit 4, and are placed in Zone NP 25 (Sphenolithus ciperoensis Zone). A small sample from the core catcher of Core 43 is quite different, inasmuch as Sphenolithus distentus, Sphenolithus predistentus, and Helicosphaera recta are present, and, together with abundant Coccolithus abisectus and common Chiasmolithus altus, indicate Zone NP 24 (Sphenolithus distentus Zone). In this sample single specimens of Reticulofenestra umbilica and of Discoaster cf. barbadiensis (not listed in Table 1) were found, but are regarded as displaced. Silicoflagellates are not present in the intercalated sediments.

Preservation of calcareous nannofossils in general is moderate, with a tendency to poor in most samples except the Oligocene samples, where preservation seems better than in the Neogene samples. Solution effects are evident, especially in the glacial part, where specimens are heavily corroded and often broken. Partial solution and secondary growth of calcite is common in the Neogene part of the section. Discoasters in the lower Miocene are heavily overcalcified in most species and show well-developed crystal faces; they often show alternating fusion of rays which mask their original appearance (Martini, 1976), and can only be identified as belonging to the Discoaster deflandrei group having bifurcating ends at rays. Discoaster druggi, which has only notches at the ends of rays, without bifurcation, is identified by its different appearance even in the overcalcified state, and is listed as Discoaster cf. druggi in the fossil list (Table 1). Another species gaining calcite from the solution of more delicate species is Coccolithus pelagicus, which dominates the assemblages in the upper Miocene and lower Pliocene. In this species secondary calcite has been deposited, especially along the wall and on the elements of the distal shield, resulting in a steep wall around the central area and an overall heavy appearance of coccoliths (Plate 2, Figure 5).

\section{SITE 409}

At Site $409\left(62^{\circ} 36.98^{\prime} \mathrm{N}, 25^{\circ} 57.17^{\prime} \mathrm{W}\right.$, water depth 832 $\mathrm{m})$, two lithologic units were differentiated by the shipboard party. The upper unit $(29.5$ to $58.9 \mathrm{~m})$ is calcareous sandy 
mud with several turbidites, and the lower unit (58.9 to 80.1 $\mathrm{m}$ ) is reported to consist of mostly structureless calcareous muds. Samples from both units contain calcareous nannofossils, but are barren of silicoflagellates. Limestone intercalated in basalt at 130.0 to 131.6 meters (Core 13) was not investigated.

In the uppermost sample available $(2-1,7-8 \mathrm{~cm})$, calcareous nannofossils are dominated by Gephyrocapsa aperta and Emiliania huxleyi, and can be placed in the Emiliania huxleyi Zone (NN 21). Sample 4-1, 16-17 cm contains no calcareous nannofossils. In Sample 4-5, 41-42 $\mathrm{cm}$, there is a mass occurrence of Coccolithus pelagicus, with normal and large specimens; since neither Emiliania huxleyi nor Pseudoemiliania lacunosa was found, this occurrence belongs in Zone NN 20 (Gephyrocapsa oceanica Zone). Pseudoemiliania lacunosa is present in Samples 5-1, 8-9 cm to 7-6, 41-42 cm, which are placed in the combined Zones NN 16/19, because species commonly used for subdivision in this interval are missing in the Reykjanes Ridge area. The presence of Cyclococcolithus macintyrei in Sample 7-1, 8-9 cm, however, may indicate that this sample already belongs in the Pliocene, since Cyclococcolithus macintyrei seems to have its last occurrence elsewhere at or near the Pliocene/Pleistocene boundary (Müller, 1976). Within this interval, Sample 5-4, $120-121 \mathrm{~cm}$ is dominated by Geophyricapsa aperta, whereas the other samples are dominated by Coccolithus pelagicus. The presence of such layers was also reported from the same interval in the Norwegian-Greenland Sea by Müller (1976). Other species present and their distribution are listed in Table 2. Reworked Cretaceous species are rare in the glacial part at Site 409 , and were only noted in Sample 6-1, 6-7 cm. Preservation of calcareous nannofossils is moderate in most samples, with a tendency to poor in the lowermost samples investigated.

\section{CONCLUSIONS}

1. Calcareous nannofossil assemblages from the Reykjanes Ridge area are comparable to those from the Rockall Bank (Leg 12) in the Miocene and part of the Pliocene (discoasters, Scyphosphaera species, etc.), whereas in most of the Pliocene and in the glacial part the assemblages are very similar to those from the Norwegian-Greenland Sea, which are clearly dominated by only a few species (Coccolithus pelagicus, Reticulofenestra sp., Gephyrocapsa aperta, etc.).

2. A remarkable abundance of Zygrhablithus bijugatus, noted in the upper Oligocene of Site 352 on the Iceland-Faeroe Ridge (Müller, 1976) and of Sites 116 and 117 on the Rockall Plateau (Perch-Nielsen 1972), and indicating shallow water or "near-shore" conditions, has its counterpart in a Zygrhablithus bijugatus-Discolithina spp. assemblage in Hole 407 on the northwest flank of Reykjanes Ridge.

3. The fluctuation of discoaster distribution seems to indicate the presence of somewhat warmer water masses for environments represented in the lower Miocene (upper part of NN 1 to NN 2), in part of the upper Miocene (NN 11), and part of Zones NN 12/15, where Scyphosphaera species have a certain distribution in the Reykjanes Ridge area.
4. Silicoflagellate distribution in the lower Miocene and upper Miocene to Quaternary in the Reykjanes Ridge area is similar to that in the Norwegian-Greenland Sea (Martini and Müller, 1976), although assemblages do not show the abundance and diversity of the latter area.

5. Site 407 is on anomaly 13 (about 38 m.y.), but youngest basalts encountered are not older than 24 to 26 m.y., according to the calcareous nannofossils, and are much younger than expected. Also, the several million year gap in volcanism, indicated by the intercalated sediments (discussed in a preliminary report in Geotimes by Luyendyk et al., 1977), may not necessarily be correct. Cores 35 and 36 can be placed in nannofossil Zone NP 25 ( 24 to 26 m.y.) and Core 43 in Zone NP 24 (26 to 32 m.y.). The difference in age between these intercalated sediments may be less than 1 million years or may be as much as 6 million years, but they are still well above anomaly 13 .

6. At Site 407 , a hiatus occurs between lithologic Units 2 and 3 , and according to the calcareous nannofossils includes the uppermost parts of the lower Miocene, the middle Miocene, and the lowest part of the upper Miocene (nannofossil Zones NN 4 to part of NN 10).

7. In the Norwegian-Greenland Sea, a hiatus was noted between "glacial" and the underlying Tertiary at most sites (Schrader et al., 1976); the situation is very similar at Site 407 , where at the same level a hiatus is probably present.

\section{REMARKS ON SELECTED CALCAREOUS NANNOFOSSIL TAXA}

Most of the calcareous nannofossil taxa present are well documented elsewhere and need no discussion. However, a few taxa which are commonly neglected or have to be grouped together because of their small size, and which cannot be differentiated by light microscope techniques, will be discussed for better understanding especially of the fossil lists (Tables 1 and 2). Also, a few species like those of the genus Discolithina, which are figured on the plates, need some explanations.

\section{Genus CYCLOCOCCOLITHUS Kamptner, 1954, ex Kamptner, 1956 (Plate 2, Figure 4)}

As pointed out by Jafar and Martini (1974), the generic name Cyclococcolithus is validly published, and the generic name Cyclococcolithina Wilcoxon, 1970, has to be rejected.

\section{Genus HELICOSPHAERA Kamptner, 1954}

(Plate 2, Figures 2 and 3)

The generic name Helicosphaera has to be retained and the generic name Helicopontosphaera Hay and Mohler, 1967, to be suppressed, as discussed by Jafar and Martini (1975).

\section{Coccolithus radiatus Kamptner, 1955}

This species with small to medium-sized placoliths is subcircular to elliptical in shape, and seems to range from about the middle Miocene to the Quaternary. Specimens found are identical to those figured by Jafar (1975, pl. 9, fig. 10, 11, 18).

\section{Cyclolithella inflexa (Kamptner) Loeblich and Tappan, 1966} (Plate 2, Figure 9)

Oval-shaped rings consisting of two shields are present in many samples in the upper Miocene to Quaternary, and according to some SEM pictures compare well with specimens published by Stradner $(1973$, pl. 14, fig. 3-6).

\section{Genus DISCOLITHINA Loeblich and Tappan, 1963}

Members of the genus Discolithina are included by several authors in the genus $P$ ontosphaera. But since a detailed study of the relationship between 
both is still missing, in the present paper we use the generic name Discolithina for species found.

\section{Discolithina enormis Locker, 1967}

(Plate 1, Figures 1 through 4, 9)

Specimens have a relatively high wall, a cycle of large pores along the inner side of the rim, and a central area pierced by a number of small to medium-sized pores which are irregularly spaced. Forms found seem to be identical to those described by Locker (1967), on the basis of light-microscope observations. The outer circle of relatively large pores is obscured by the ascending wall, which is seen as a broad rim under the light microscope. Stratigraphic distribution is restricted to the upper Oligocene calcareous nannofossil Zone NP 25.

\section{Discolithina multipora (Kamptner ex Deflandre) Martini, 1965}

(Plate 1, Figures 7, 8, 10)

The most common form has a central area with many pores of similar size. Pores along the rim are somewhat larger, best seen in distal view. Included are specimens with more than three rows of inner pores in the central area. Variation within this species is considerable, and two extreme specimens are figured on Plate 1, Figures 7 and 8 . The true range is not entirely known, but seems to be restricted to the upper (?) Oligocene and Miocene, although it was reported by some authors as occurring in older strata.

\section{Discolithina desueta Müller, 1970}

(Plate 1, Figures 5 and 6 )

This species, described by Haq (1971, p. 83) as Pontosphaera rothi, is smaller than Discolithina multipora, has large pores in an outer cycle along the rim, and distinctly smaller pores in the central area up to three rows. Intermediate forms between this species and Discolithina multipora were already noted by Haq (1971), and are also present in the Oligocene samples of Site 407 .

\section{Emiliania huxleyi (Lohmann) Hay and Mohler, 1967}

\section{(Plate 2, Figure 12)}

Specimens in the upper Quaternary of Holes 407 and 409 are relatively robust and difficult to identify under the light microscope, but the total range of this species in the present material has been checked by SEM investigation. A well-preserved specimen is figured on Plate 2, Figure 12.

\section{Gephyrocapsa aperta Kamptner, 1963}

(Plate 2, Figure 10)

The most common form of the genus Gephyrocapsa has a fused bar which spans the central area close to the long axis. It is identical to those figured by Kamptner (1963) as $G$. aperta. This small species is difficult to identify under the light microscope in some samples, because of poor preservation, but could be identified under the scanning electron microscope. Forms slightly larger and having a fused bar across the central opening closer to the small axis belong to Gephyrocapsa oceanica Kamptner, 1943.

\section{Pseudoemiliania lacunosa (Kamptner) Gartner, 1969 (Plate 2, Figures 7 and 8)}

Perch-Nielsen (1972) noted in the Leg 12 material from the North Atlantic that this species, as identified under the light microscope, probably includes several species. In the present material, specimens from different samples show slight differences in size of central area and number of segments and slits, but otherwise seem to be within the variation range of this species. Some SEM pictures are given on Plate 2. The first occurrence of Pseudoemiliania lacunosa in Hole 407 is at Sample 8,CC, and below the last occurrence of Reticulofenestra pseudoumbilica.

\section{Reticulofenestra cf. R. tenuistriata (Kamptner) nov. comb.} (Plate 2, Figure 6)

In the upper part of lithologic Unit 3 in Hole 407, between Samples 19, $\mathrm{CC}$ and $18-3,10-11 \mathrm{~cm}$, a relatively large Reticulofenestra species is present which shows similarity to Reticulofenestra tenuistriata described as Coccolithus tenuistriatus by Kamptner (1963, pl. 2, fig. 14, 15) from the Miocene of the Pacific Ocean.

\section{Reticulofenestra sp.}

Under this name I have grouped together all small Reticulofenestra species and Coccolithus doronicoides Black and Barnes which cannot be differentiated with the light microscope. Even SEM investigations failed to find a solid base for defining species (except Coccolithus doronicoides) in the present material, because preservation is only moderate and central areas are poorly preserved.

\section{Sphenolithus sp.}

Here are included all simple sphenoliths from the $S$. moriformis-S. pacificus-S. abies group, which show quite a bit of variation, depending on the degree of overcalcification or solution, and which are difficult to differentiate in many samples of the present material.

\section{Scyphosphaera aequatorialis Kamptner, 1963}

A few specimens in Samples 8, CC to $10, \mathrm{CC}$ of Site 407 are very similar to specimens figured by Jafar (1975, pl. 3, fig. 14 and 15) in having an arched basal plate, an inflated lower part, and a simple apical end without bend

\section{Syracosphaera sp.}

Specimens of one or more Syracosphaera species were found in the lower Pliocene and "glacial" interval. They were identified by their typical extinction pattern under crossed nicols, but because of their otherwise small size and weak appearance under the light microscope, they could not be properly identified. The only specimen encountered during SEM studies is figured on Plate 1, Figure 12, and is identified as Syracosphaera pulchra Lohmann.

\section{ACKNOWLEDGMENTS}

Thanks are due to the U.S. National Science Foundation and to the Chief Scientist, Deep Sea Drilling Project, for providing the samples for the present shore-lab study. The investigation was supported by the Deutsche Forschungsgemeinschaft. SEM pictures were taken by J. Tochtenhagen with a Stereoscan Mark 2, which was provided to the Geologisch-Paläontologisches Institut der Universität Frankfurt am Main by the VW-Stiftung. My sincere thanks also go to Dr. Carla Müller for valuable discussions and for reviewing this paper.

\section{REFERENCES}

Bachmann, A., 1970. Silicoflagellaten aus dem oberösterreichischen Egerien (Oberoligozän), Verh. Geol. Bundesanst. Wien, Jg. 1970, p. 275-305.

Bukry, D., 1973. Coccolith stratigraphy, Eastern Equatorial Pacific, Leg 16 Deep Sea Drilling Project. In van Andel, T. H., Heath, G. R., et al., Initial Reports of the Deep Sea Drilling Project, v. 16: Washington (U.S. Government Printing Office), p. 653-711.

Ciesielski, P. F., 1975. Biostratigraphy and Paleoecology of Neogene and Oligocene silicoflagellates from cores recovered during Antarctic Leg 28, Deep Sea Drilling Project. In Hayes, D. E., Frakes, L. A., et al., Initial Reports of the Deep Sea Drilling Project, v. 28: Washington (U.S. Government Printing Office), p. 625-691.

Haq, B. U., 1971. Paleogene calcareous nannoflora. Part II: Oligocene of Western Germany, Acta Univ. Stockholm., Stockholm Contr. Geol., v. 25, p. 57-97.

Hoffmann, N., 1976. Zur Bedeutung des kalkigen Nannoplanktons in der marinen Geologie und erste biostratigraphische Untersuchungsergebnisse von Sedimentkernen des Rockall-Plateau (Nordostatlantik), $Z$. Geol. Wiss. Berlin, v. 4, p. 647-665.

Jafar, S. A., 1975. Calcareous nannoplankton from the Miocene of Rotti, Indonesia, Verh. Koninkl. Nederl. Akad. Wet., Afd. Nat., 1. R., v. 28, p. 1-99 
Jafar, S. A. and Martini, E., 1974. On the retention of the generic name Cyclococcolithus Kamptner, 1954, ex Kamptner, 1956, and the rejection of the generic name Cyclococcolithina Wilcoxon, 1970. Micropaleontology, v. 20, p. 367-368.

1975. On the validity of the calcareous nannoplankton genus Helicosphaera, Senckenbergiana lethaea, v. 56, p. 381-397.

Kamptner, E., 1963. Coccolithinen-Skelettreste aus Tiefseeablagerungen des Pazifischen Ozeans, Ann. Naturhist. Mus. Wien, v. 66, p. 139-204.

Ling, H. Y., 1972. Upper Cretaceous and Cenozoic silicoflagellates and ebridians, Am. Paleontol. Bull., v. 62, p. $135-229$.

1973. Silicoflagellates and ebridians from Leg 19. In Creager, J. G., Scholl, D. W., et al., Initial Reports of the Deep Sea Drilling Project, v. 19: Washington (U.S. Government Printing Office), p. 751-775.

Locker, S., 1967. Neue, stratigraphisch wichtige Coccolithophoriden (Flagellata) aus dem norddeutschen Alttertiär, Monatsber. deutsch. Akad. Wiss. Berlin, v. 9, p. $758-768$.

Luyendyk, B., Cann, J. R., et al., 1977. In the North Atlantic'young and hot' drilling, Geotimes, v. 22, p. 25-28.

Martini, E., 1971. Standard Tertiary and Quaternary calcareous nannoplankton zonation, Second Planktonic Conf. Proc., Roma 1970, v. 2, p. 739-785.

1972. Silicoflagellate zones in the late Oligocene and early Miocene of Europe, Senckenbergiana lethaea, v. 53, p. $119-122$.

1976. Cretaceous to Recent calcareous nannoplankton from the central Pacific Ocean (DSDP Leg 33). In Schlanger, S. O., Jackson, E. D. et al., Initial Reports of the Deep Sea Drilling Project, v. 33: Washington (U.S. Government Printing Office), p. 383-423.

Martini, E. and Müller, C., 1975. Calcareous nannoplankton from the type Chattian (Upper Oligocene), Sixth Congr. Mediterr. Neogene Strat. Proc., v. 1, p. 37-41.
1976. 'Eocene to Pleistocene silicoflagellates from the Norwegian-Greenland Sea (DSDP Leg 38). In Talwani, M., Udintsev, G., et al., Initial Reports of the Deep Sea Drilling Project, v. 38: Washington (U.S. Government Printing Office), p. 857-895.

Müller, C., 1976. Tertiary and Quaternary calcareous nannoplankton in the Norwegian-Greenland Sea, DSDP, Leg 38. In Talwani, M., Udintsev, G., et al., Initial Reports of the Deep Sea Drilling Project, v. 38: Washington (U.S. Government Printing Office), p. 823-841.

Perch-Nielsen, K., 1972. Remarks on late Cretaceous to Pleistocene coccoliths from the North Atlantic. In Laughton, A. S., Berggren, W. A., et al., Initial Reports of the Deep Sea Drilling Project, v. 12: Washington (U.S. Government Printing Office), p. 1003-1069.

Sanfilippo, A., Burckle, L. H., Martini, E., and Riedel, W. R., 1973. Radiolaria, diatoms, silicoflagellates and calcareous nannoplankton in the Mediterranean Neogene, Micropaleontology, v. 19, p. 209-234.

Schrader, H. J., Bjørklund, K., Manum, S., Martini, E., and van Hinte, J., 1976. Cenozoic biostratigraphy, physical stratigraphy and paleooceanography in the Norwegian-Greenland Sea, DSDP Leg 38 paleontological synthesis. In Talwani, M., Udintsev, G. et al., Initial Reports of the Deep Sea Drilling Project, v. 38: Washington (U.S. Government Printing Office), p. 1197-1211.

Steininger, F., Rögl, F., and Martini, E., 1976. Current Oligocene/Miocene biostratigraphic concept of the Central Paratethys (Middle Europe), Newsl. Stratigr., v. 4, p. 174-202.

Stradner, H., 1973. Catalogue of calcareous nannoplankton from sediments of Neogene age in the eastern North Atlantic and Mediterranean Sea. In Ryan, W. B. F., Hsü, K. J., et al., Initial Reports of the Deep Sea Drilling Project, v. 13: Washington (U.S. Government Printing Office), p. 1137-1199. 
PLATE 1

Oligocene to Quaternary Calcareous Nannofossils

Figures 1-4, 9 Discolithina enormis Locker.

1. Distal Side, $4950 \times$. Sample 407-35-1, $100-102 \mathrm{~cm}$.

2, 3. Distal side, $5000 \times$.

4. Proximal side, $6600 \times$.

9. Proximal side, $5000 \times$. Sample 407-30, CC. Upper Oligocene, NP 25.

Figures 5, 6 Discolithina desueta Müller.

5. Distal side, $5000 \times$.

6. Proximal side, $5000 \times$. Sample 407-30, CC. Upper Oligocene, NP 25.

Figures 7,8,10 Discolithina multipora (Kamptner).

7. Distal side, $5000 \times$. Sample 407-30, CC.

8. Distal side, $4950 \times$. Sample 407-19, CC. Lower Miocene, NN 3.

10. Proximal side, $5000 \times$. Sample 407-30, CC. Upper Oligocene, NP 25.

Figure 11 Discolithina cf. D. callosa Martini. Proximal side, $6600 \times$. Sample 407-10, CC. Lower Pliocene, NN $12 / 15$.

Figure 12 Syracosphaera pulchra Lohmann. Distal side 10,000 $\times$. Sample 407-5, CC. "Glacial," NN 16/19. 
PLATE 1
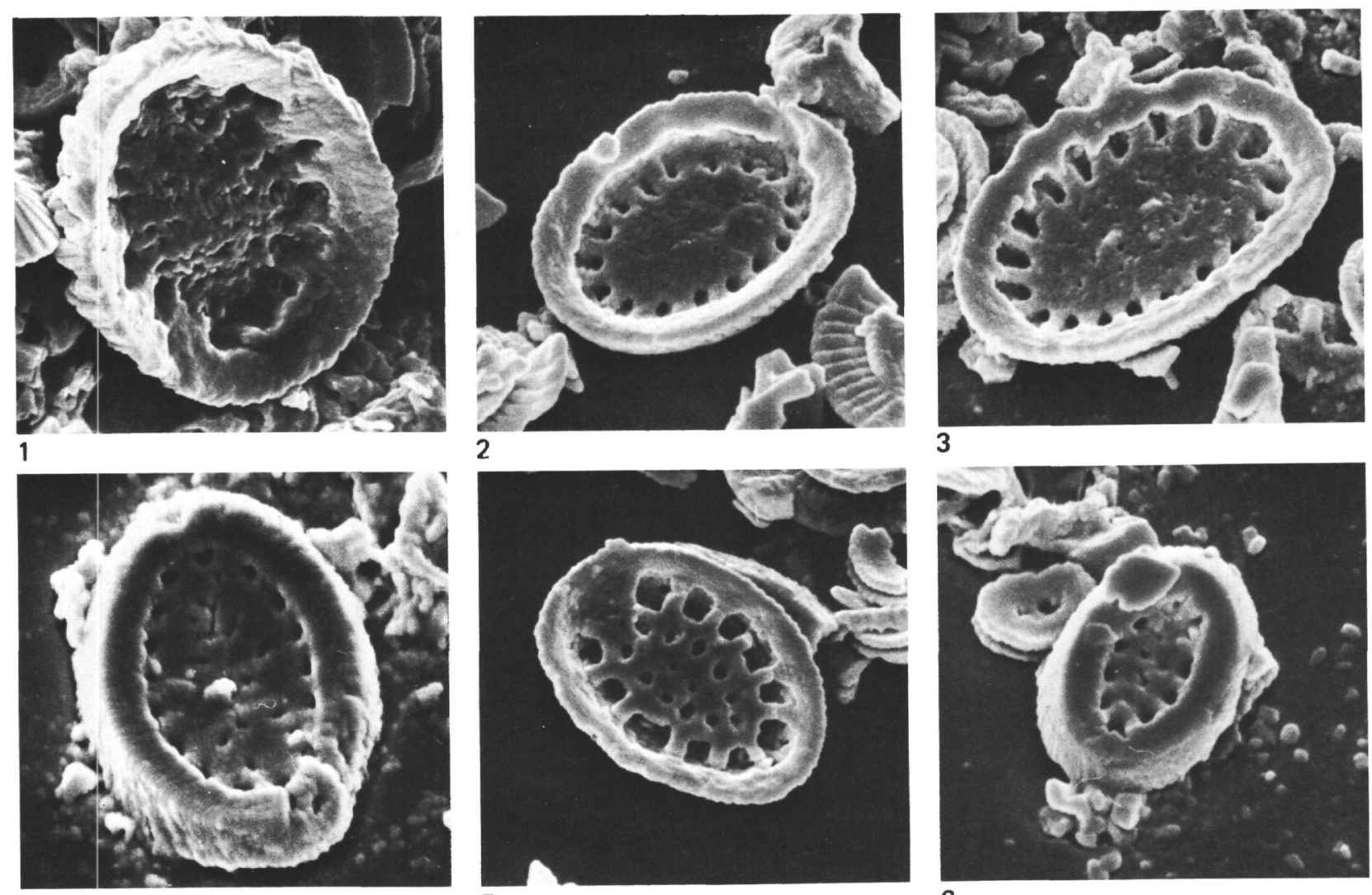

4

5
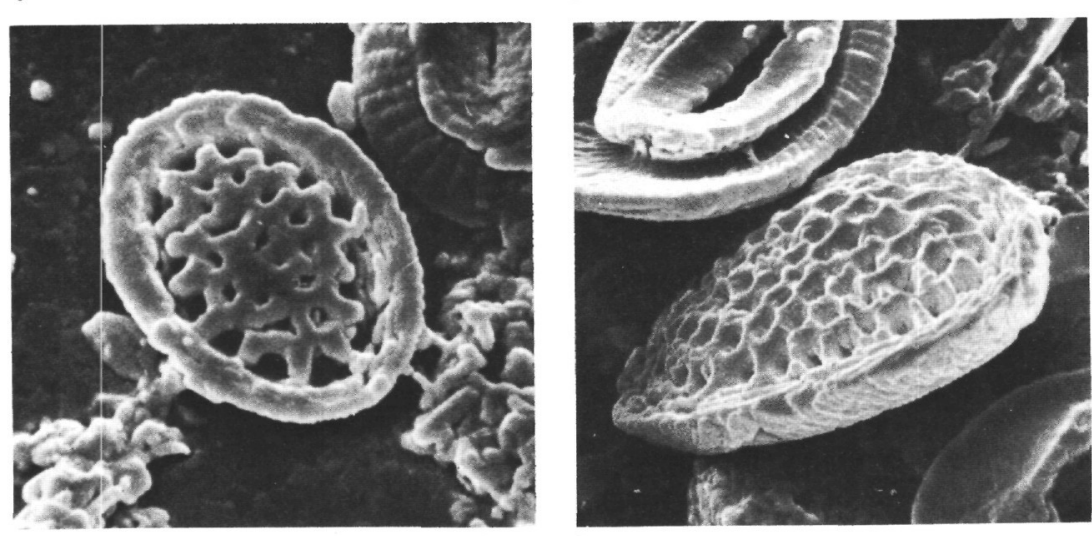

7

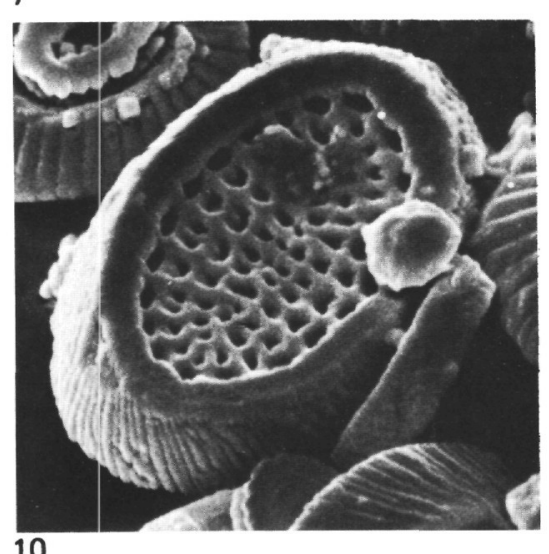

8

\section{6}
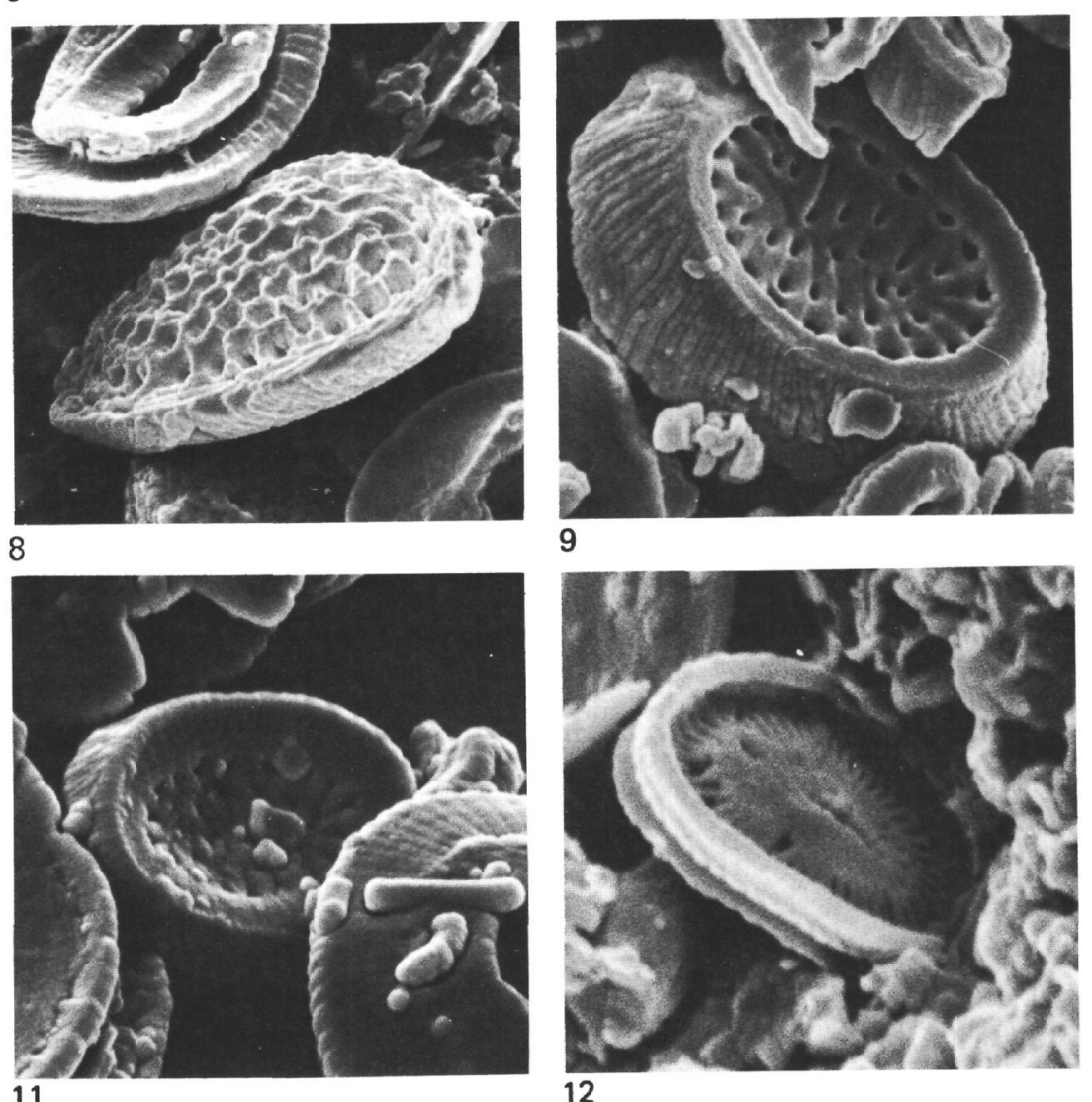


\section{PLATE 2}

Neogene and Quaternary Calcareous Nannofossils

Figure 1 Discoaster sp. ex Discoaster deflandrei group. $3300 \times$. Sample 407-22-1, 55-56 cm.

Lower Miocene, NN 1.

Figure 2 Helicosphaera ampliaperta Bramlette and Wilcoxon.

Primal side, $6600 \times$. Sample 407-22, CC.

Lower Miocene, NN 2.

Figure 3 Helicosphaera wallichii Lohmann. Proximal side, $5000 \times$ (not listed in Table 1).

Sample 407-7, CC. Lower Pliocene, NN 12/15.

Figure $4 \quad$ Cyclococcolithus macintyrei Bukry and Bramlette.

Proximal side, $3300 \times$. Sample 407-17, CC.

Upper Miocene, NN 10?

Figure 5 Coccolithus pelagicus (Wallich). Distal side, $3300 \times$. Sample 407-3-1, 15-16 cm. Quaternary, NN 20.

Figure 6 Reticulofenestra $\mathrm{cf}$. $R$. tenuistriata (Kamptner). Proximal side, $3300 \times$. Sample 407-19, CC. Lower Miocene, NN 2.

Figure 7 Pseudoemiliania lacunosa (Kamptner). Distal side, 10,000 $\times$. Sample 407-7, CC. Lower Pliocene, NN 12/15.

Figure 8 Pseudoemiliania lacunosa (Kamptner). Distal side, 10,000 $\times$. Sample 407-5, CC. "Glacial,", NN 16/19.

Figure 9 Cyclolithella inflexa (Kamptner). Proximal side, 10,000 $\times$. Sample 407-10, CC. Lower Pliocene, NN 12/15

Figure 10 Gephyrocapsa aperta Kamptner (= Gephyrocapsa ericsonii McIntyre and Bé). Distal side, 10,000 ×. Sample 407-1, CC. Quaternary, NN 21.

Figure 11 Gephyrocapsa oceanica Kamptner. Distal side, 10,000 $\times$. Sample 407-3-1, 15-16 cm. Quaternary, NN 20.

Figure 12 Emiliania huxleyi (Lohmann). Distal side, 10,000 $\times$. Sample 407-1, CC. Quaternary, NN 21. 
PLATE 2
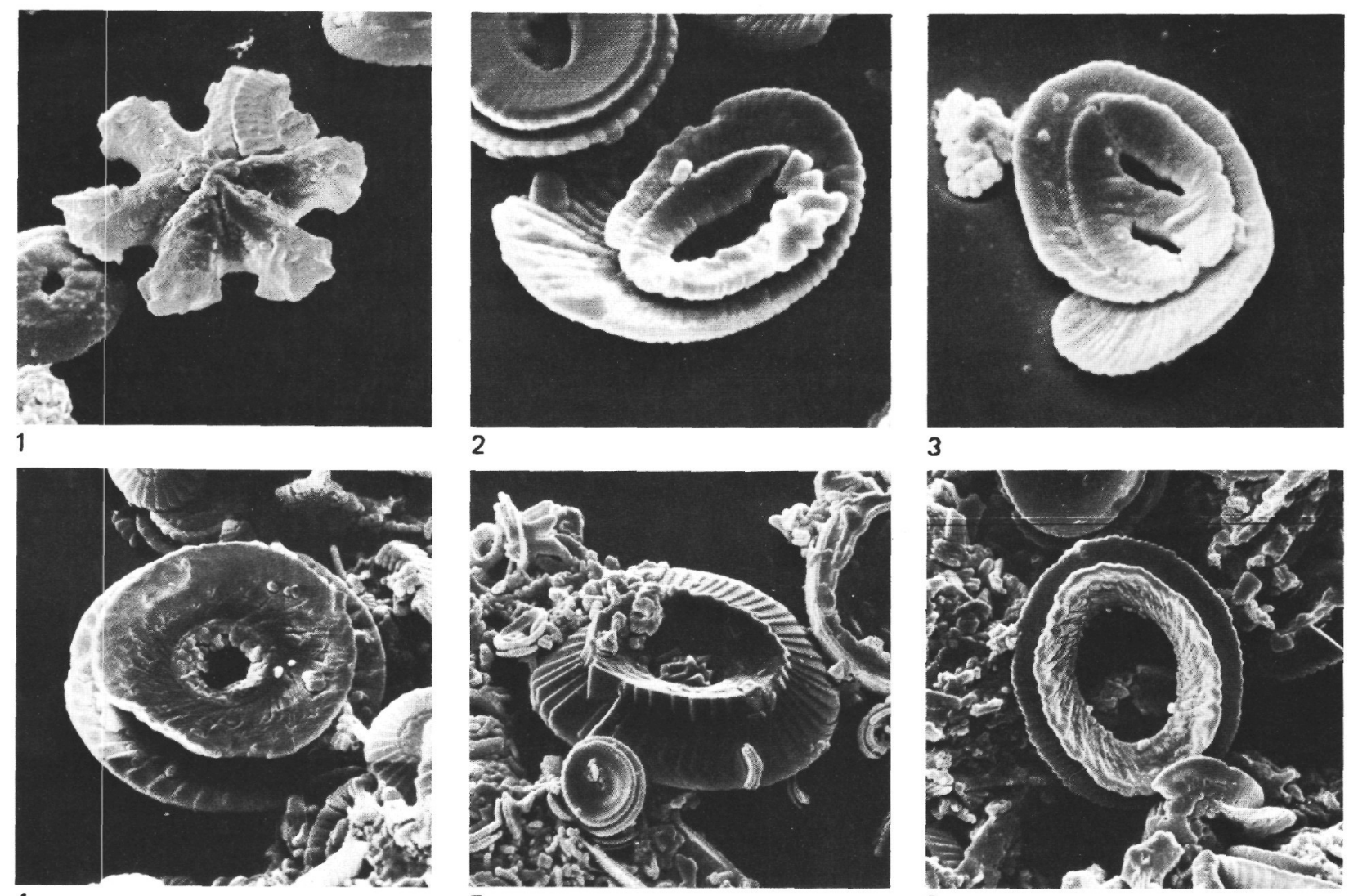

4

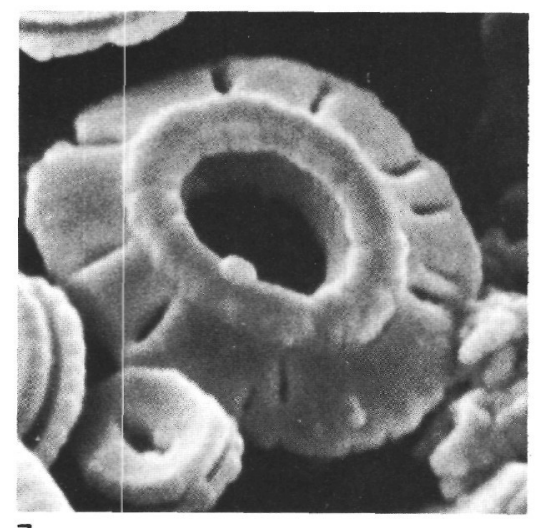

7

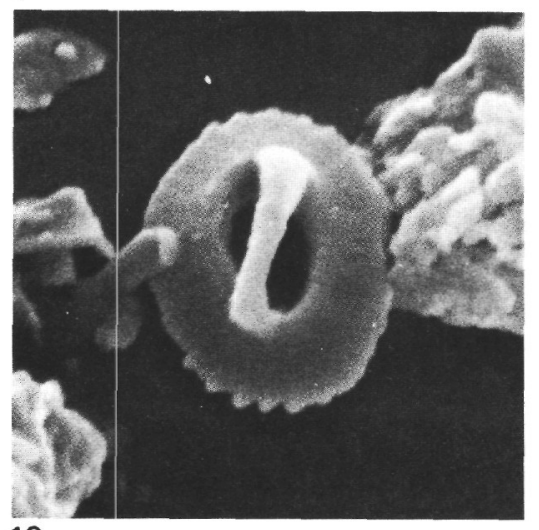

5

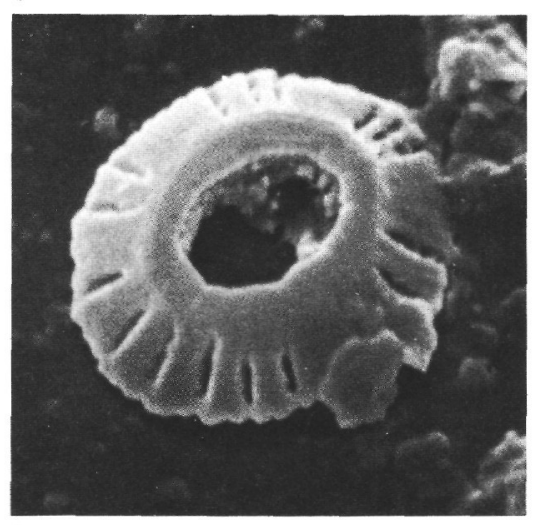

8

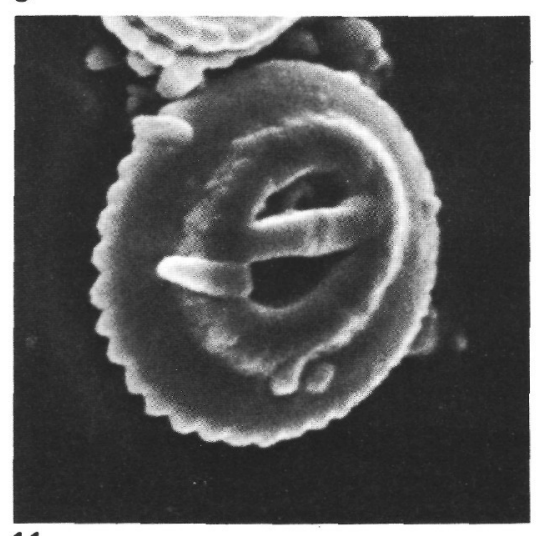

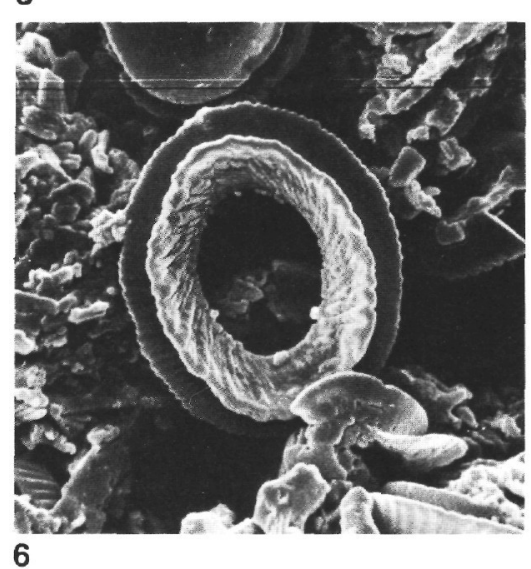

6

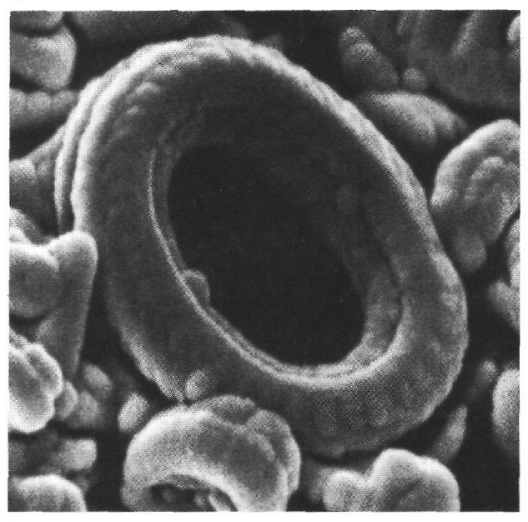

9

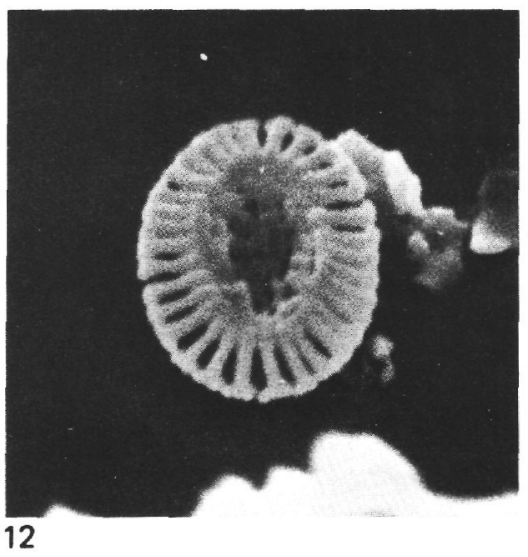


PLATE 3

Neogene and Quaternary Silicoflagellates (All specimens LM and Approximately $600 \times$ )

Figure 1 Pseudorocella corona Deflandre. Distal side. Sample 407-21-1, $30-31 \mathrm{~cm}$. Lower Miocene, Naviculopsis navicula Zone.

Figure 2 Corbisema flexuosa (Stradner). Distal side. Sample 407-26, CC. Lower Miocene, Naviculopsis biapiculata Zone.

Figure 3 Corbisema triacantha (Ehrenberg). Distal side. Sample 407-22-3, 25-26 cm. Lower Miocene, Naviculopsis lata Zone.

Figure 4 Distephanus longispinus (Schulz). Distal side. Sample 407-19, CC. Lower Miocene, Naviculopsis navicula Zone.

Figure 5 Distephanus speculum (Ehrenberg). Specimen with 3 apical windows, transitional form to Distephanus boliviensis, distal side. Sample 407-7, CC. Lower Pliocene, Distephanus boliviensis Zone.

Figure 6 Distephanus boliviensis (Frenguelli). Distal side. Sample 407-11-1, 5-6 cm. Lower Pliocene, Distephanus boliviensis Zone.

Figure 7 Distephanus octonarius (Ehrenberg). Distal side. Sample 407-2, CC. Quaternary, Distephanus speculum Zone.

Figure 8 Naviculopsis biapiculata (Lemmermann). Distal side, spines, broken off. Sample 407-29-5, 10-11 cm. Lower Miocene, Naviculopsis biapiculata Zone.

Figure 9 Naviculopsis lata (Deflandre). Distal side. Sample 407-22-3, 25-26 cm. Lower Miocene, Naviculopsis navicula Zone.

Figure 10 Mesocena apiculata (Schulz). Sample 407-21-1, 30-31 cm. Lower Miocene, Naviculopsis navicula Zone.

Figure 11 Mesocena elliptica Ehrenberg. Sample 407-10, CC. Lower Pliocene, Distephanus boliviensis Zone.

Figure 12 Mesocena diodon Ehrenberg. Sample 407-11-1, 5-6 cm. Lower Pliocene, Distephanus boliviensis Zone. 
PLATE 3
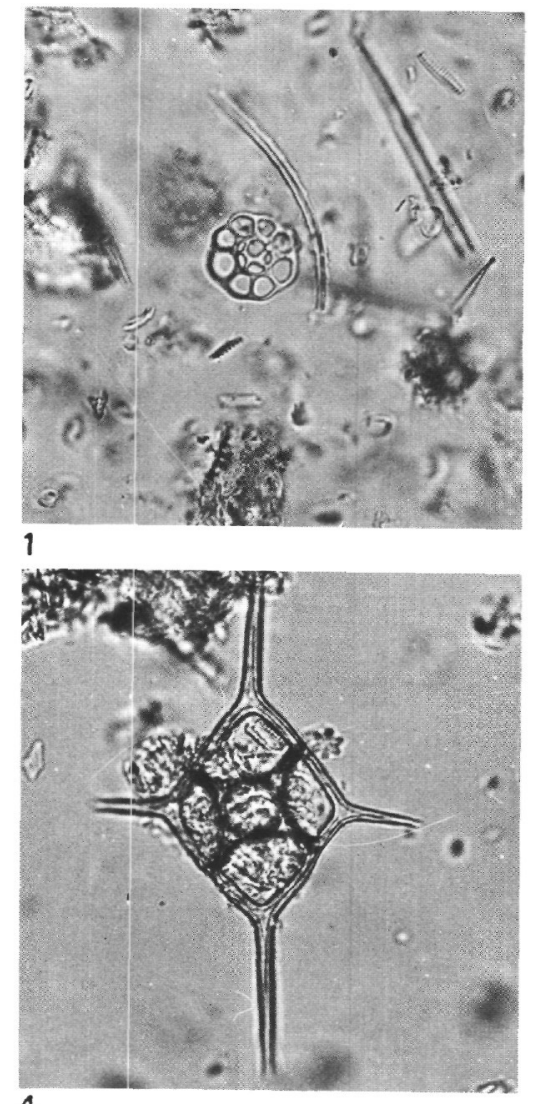

4
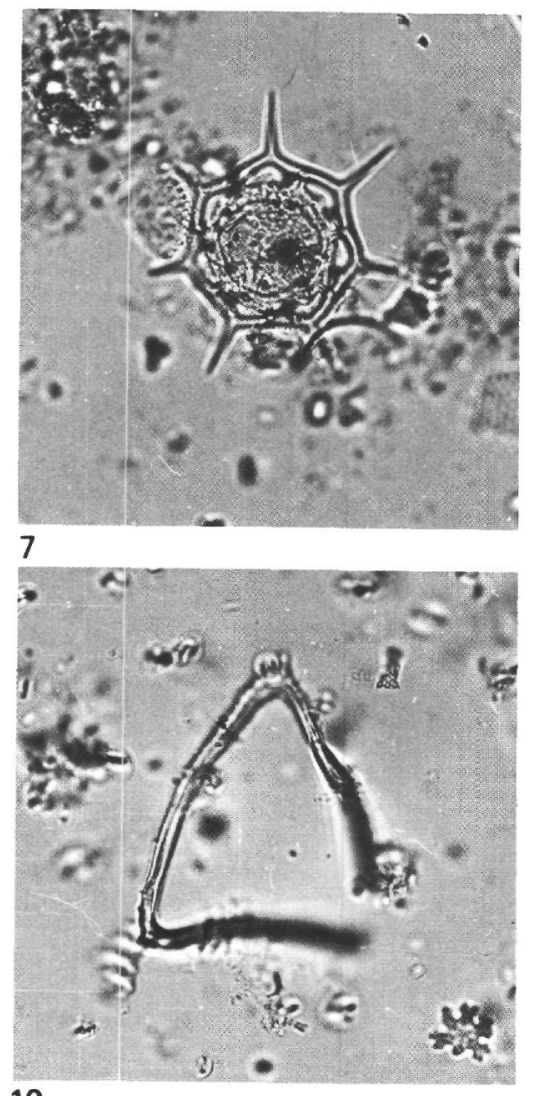

10

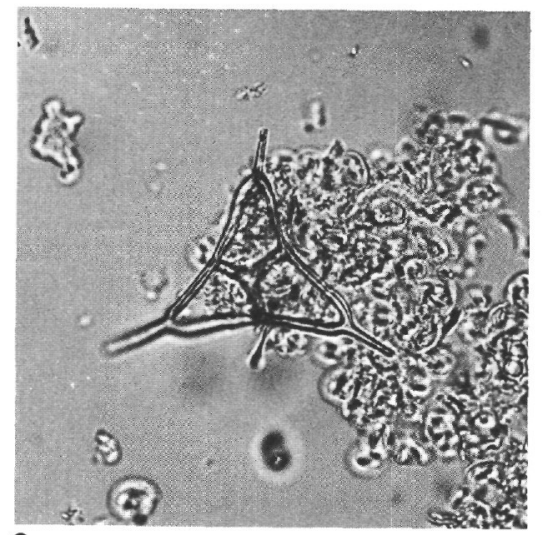

2

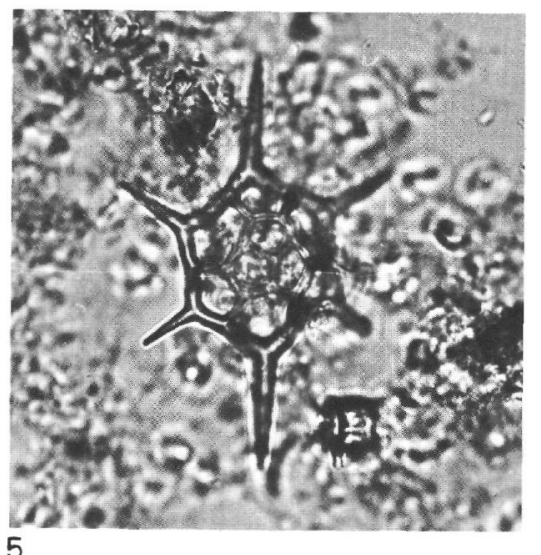

5

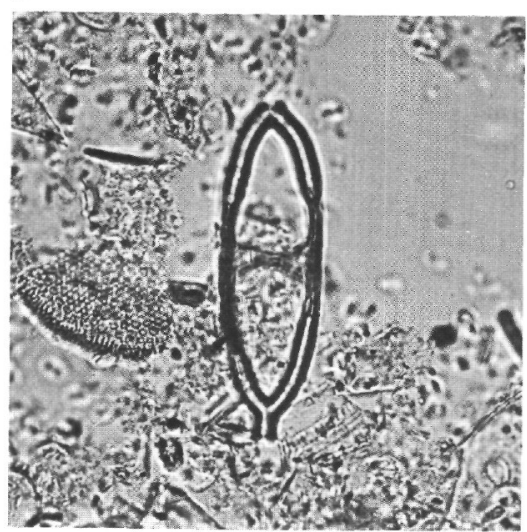
8

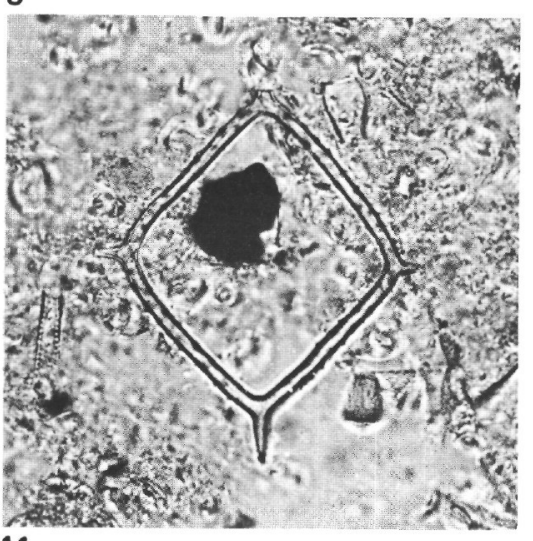
11
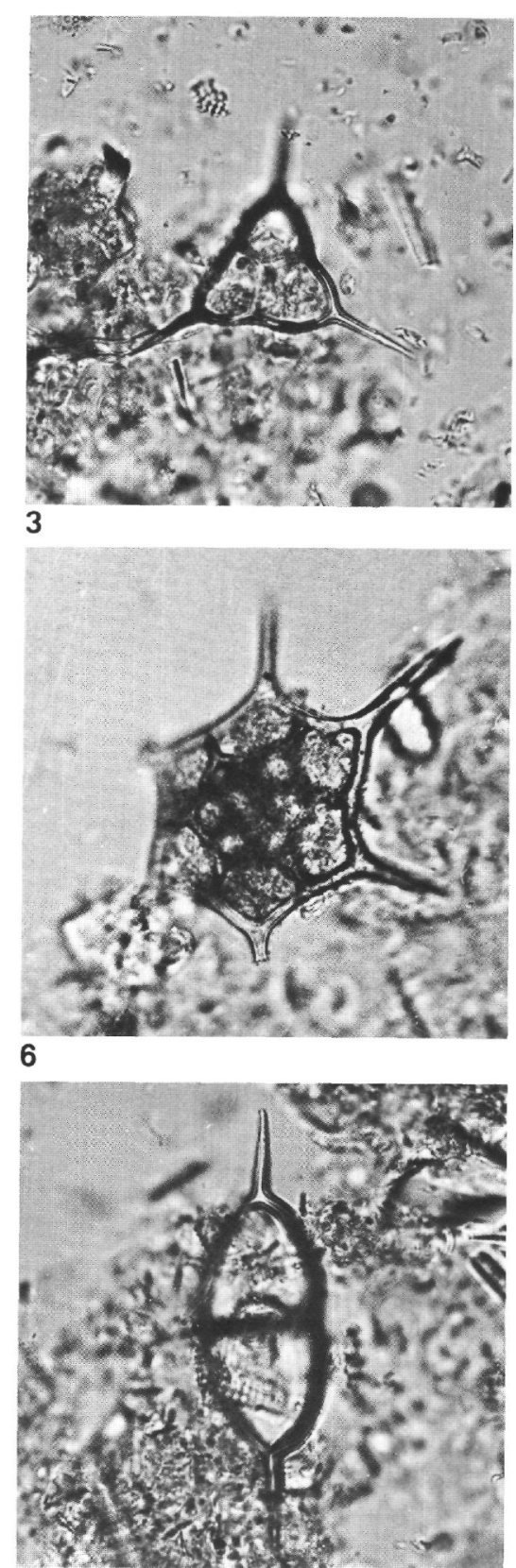

9

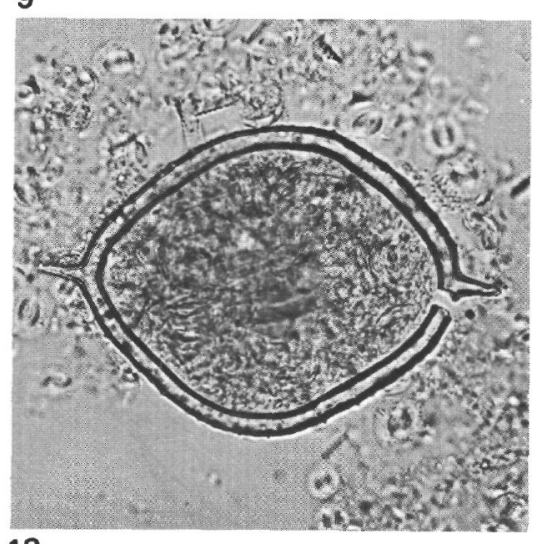

12 